\title{
The Evolution of Shea Butter's "Paradox of paradoxa" and the Potential Opportunity for Information and Communication Technology (ICT) to Improve Quality, Market Access and Women's Livelihoods across Rural Africa
}

\author{
Julia Bello-Bravo ${ }^{1}$, Peter N. Lovett ${ }^{2, *}$ and Barry R. Pittendrigh ${ }^{3}$ \\ 1 Center for African Studies and Illinois Strategic International Partnerships, \\ Office of the Associate Provost for International Affairs, University of Illinois at Urbana-Champaign, \\ Suite 401, MC-417, 507 E. Green Street, Champaign, IL 61820, USA; \\ E-Mail: juliabb@illinois.edu \\ 2 Production \& Supply Chain, Savannah Nutrition Ltd., 15 Guilder Lane, SP1 1HW Salisbury, UK \\ 3 Department of Entomology, University of Illinois at Urbana-Champaign, \\ 505 South Goodwin Avenue, Urbana, IL 61801, USA; E-Mail: pittendr@illinois.edu \\ * Author to whom correspondence should be addressed; E-Mail: shea.expert@gmail.com; \\ Tel.: +1-217-333-6538; Fax: +1-217-244-3499.
}

Academic Editor: Rachel J. C. Chen

Received: 31 January 2015 / Accepted: 29 April 2015 / Published: 8 May 2015

\begin{abstract}
Shea trees grow across 4 million $\mathrm{km}^{2}$ of sub-Saharan Africa. Shea parklands provide a sustainable source of edible fat (shea butter) that, in terms of volume, is currently second only to cocoa butter as a vegetal source of stearic acid in the multi-billion dollar chocolate and cosmetic sectors. However, in terms of international trade, shea has been opaque to consumers of edible products (where the majority of shea exports end their global journey) and actually only well-known in western markets as a cosmetic ingredient. The millions of women collectors have been disconnected from global supply chains, as the majority of their sheanuts are factory processed, supplied by traders who, in many cases, do not understand quality issues nor share knowledge with their village-based collectors - this is the "Paradox of paradoxa". This review provides the background to this issue by contextualizing the industry and describing how weak post-harvest quality control impacts the shea supply chain. The paper then explains how this knowledge was incorporated into a 3D animation available for free transmission to rural African audiences and viewing on portable devices like video capable mobile phones. This tool offers the
\end{abstract}


potential of low-cost multiple benefits to users, which we term here a win-cubed [win ${ }^{3}$ ] opportunity, where women collectors can receive free knowledge of using less resources to produce higher quality shea kernels which in turn offer higher extraction yields, lowering production costs, of a better and more marketable product.

Keywords: African women; shea butter; chocolates; cosmetics; post-harvest quality; ICT knowledge transfer

\section{Introduction}

Globalization is having a dramatic impact on women that depend on the informal economy for income generating activities. Globalization has the potential to be negative or positive, for women in African countries, depending on the product, trade and value chain. Some goods like shea butter, which is a product of the shea tree (Vitellaria paradoxa syn. Butyrospermum paradoxum or parkii), have increasing international demand as an ingredient in personal care and edible products. This commodity is now attractive for markets across Europe, America and Asia, and is sourced from women in West, Central and East African countries who have traditionally collected, processed and used shea butter for many centuries, probably for millennia [1].

These women now have the opportunity to participate in the commercialization of shea in the international marketplace, however, they often experience challenges at the beginning of the shea value chain that impede their ability to obtain higher prices as compared to what they should expect with higher quality and more consistent products. Part of the problem is that while women well understand the needs of the local market for home-grown commodities (like shea), international markets - that usually demand different quality, often at higher standards, with more consistency - are opaque to them. Women who work in rural Africa, however, usually have little or no access to the requisite information and knowledge that would allow them to benefit from improvement to their products and increase value addition upstream in the value chain. In general, many rural women of Sahel-Savannah Africa are still disconnected from the global shea market. This is the "Paradoxa of paradoxa" [2]. A dire situation where the majority of global [western] knowledge associates shea butter as being handmade and bought, at fair prices, from African village women before use in luxury cosmetics. Whereas, in reality, more than $90 \%$ of all shea destined for foreign markets-whether for edible use [in chocolate, margarines, ice creams, shortenings, puff pastry, fondant fillings, etc.] or cosmetics - is locally traded from the villages simply as low quality shea kernels destined for industrial processing plants. These are sourced from women collectors who are typically not directly linked with feedback mechanisms to inform other aspects of the shea value chain. Concurrently, they typically have not had easy access to knowledge associated with improve shea practices in the beginning the shea value chain that are ultimately critical for all downstream aspects of use of shea on consumer products. If women can access this information and adopt appropriate changes to their methods, they can then produce enough products consistent with the needs of the international marketplace. With the result that, these women are then, more able to compete and potentially gain a better price for their skills and labor. 
In this paper, we discuss the participation of rural women in a specific income generating activity involving harvesting, production and sale of shea products, a species botanically recorded across twenty-one countries in Sub-Saharan Africa, also known as the shea zone, along a $6000 \mathrm{~km}, 500 \mathrm{~km}$ wide belt of the Sahel-Savannah [3]. We explore the potential role of women in the shea value chain that could provide them with economic opportunities and empowerment, especially where educational steps can help facilitate such improvements. Understanding these sustainable and entrepreneurial activities, based on local research for development (R4D) innovations, coupled with the needs of the international marketplace, has the potential to bring more resources to women based at the furthest, most difficult to reach point in the shea supply chain in rural Africa. We then explore a recent research innovation in the processing of sheanuts and discuss the potential for delivery of educational programs that might be used to help women produce a higher quality product at the beginning of the value chain. To this end, we explore recent literature regarding the use of 2D and 3D animations in educating low literate populations in rural settings in Africa.

\section{Shea Tree as a Traditional Crop and Domestic Commodity}

The shea tree grows in the Sahel-Savannah belt, which (with the addition of South Sudan) includes twenty-one sub-Saharan Africa countries and extends from Senegal, in the West, to Ethiopia, in the East [4-6], and has long had a significant positive impact on the human populations living in these areas, providing a staple edible oil, fuel wood, building material, soil protection and honey from the bee pollinators.

The shea tree is considered by some, to be a semi-domesticated tree crop having been through centuries of cyclical unconscious on-farm selection [7]; it is both endemic to the Sahel-Savannah region of sub-Saharan Africa and it is a traditionally protected indigenous tree in many of the areas where it grows. People, cattle, bats, birds and other animals disseminate the seeds [5], however, the trees are not traditionally planted in a domesticated manner [4,5,8,9], but rather the decision to keep or to cut naturally regenerating saplings as a component of an agroforestry system, means the trees are selectively managed, with the result that semi-domestication is potentially occurring through the process that [9] describes as automatic or unconscious selection. Many indigenous agricultural annual and perennial crops have been domesticated, are still cultivated and continue to be traded in large volumes across West-Central Africa, a region that [10] refers to as part of a vast sub-Saharan "noncenter" of agricultural origin. Across West Africa, it has been noted that this process has resulted in an increasing density of desirable traits in shea trees maintained in parklands as opposed to natural woodland formations, e.g., fruit yield, sweetness and fat content $[7,8,11]$.

It has been suggested that the shea trees produce fruits around 15-20 years of age and they can live hundreds of years [5] although author's personal observations have noted that planted seed can produce fruiting individuals within 5-9 years and without carbon dating or dendrochronology studies, longevity is unknown. The fruits are harvested around May until September, coinciding with the rainy season [5]. The genetic variability of shea is noted to be high [7,8,11-14] and there is no tradition of planting trees, as shea is highly effective in propagating itself in this environment. Recent work, however, with micro-propagation, rooting cuttings and grafting may allow opportunities to formally domesticate and enrich parklands through selection and planting of more productive shea trees [15-18]. 
Such technological advances may ultimately reshape the economics of sheanuts produced; however, in the foreseeable future sheanut production will likely remain in the hands of local women who collect the fruits from the semi-domesticated wild-managed parkland trees. An understanding of the ecology of the shea parkland system as well as the socio-economic role of communities and individuals in its management, are crucial to ensuring this production system remains sustainable and is not perceived with too low a value. If the perceived value does collapse, there is a high probably that a Land Use Change (LUC) will result, dramatically impacting resource sustainability, as is already occurring in many locations across shea zone. Thus, it is critical to develop strategies to enable women to produce high quality shea nuts for storage at the beginning of the shea value chain.

\section{Shea Production and Trade across the Millennia}

Determining an accurate date of the first human use and trade of shea is challenging and is a subject of debate in the academic community. The early shea butter commerce can be tracked in ancient Egyptian trade in an apparently abundant vegetable oil (hknw [sic] oil) during the reign of King Merenre, approximately 4300 years before present (b.p.) from the Land of Yam or Punt. This is due to the fact that these locations could be in what is now South Sudan and Uganda, towards the source of the Nile River [19], or in Tchad. Transport could have been along ancient caravan routes between Lake Tchad and the Nile valley, as suggested by approximately 4000 year b.p. inscription mentioning Mentuhotep II, seen at Jebel Uweinat on the, so-called, Abu Ballas Trail. Although it is likely that shea's ecological boundary was further north during the more humid mid-Holocene period, as explained below, actively managed shea parklands are now spread throughout all of these countries. Furthermore, shea wood (bois de karité) is the only one of the woods thought to have been imported by Ancient Egyptians from southern countries and used to make thirteenth century statuettes that has actually been identified in both the Queen Ahmose-Nefertari and Lady Tuya figurines now maintained in the Louvre [20]. Additionally, gas chromatography-mass spectrometry analysis of hair from ancient Egyptian mummies (2600-3500 years b.p.) revealed the use of a stearic acid (18:0) rich gel [21], which introduces the possibility that shea could have been used at this earlier time.

Some of the earliest convincing evidence [22,23], for sheanut trees being utilized, comes from an archaeological site known as Saouga, which dates to approximately 1000 years b.p. in northern Burkina Faso. Numerous shell fragments were found there, and that, together with the presence of Vitellaria charcoal at the site, suggests that it is unlikely this material was imported from another area, as only shea butter or de-corticated kernels are traded. Additionally, other plant species are present at this site, which suggests that Saouga received more rainfall in the past with millet as the basic crop cultivated in agroforestry parklands; currently millet is being cultivated $\sim 100 \mathrm{~km}$ south of the site. Höhn and Neumann [24] further suggested that agroforestry parklands, intercropped with millet, began to be cultivated around 2000-2500 years b.p. in north Burkina Faso, as patterns of climatic aridity were moving southwards. When you take all of this information into account it suggests that farmed parklands, of which shea is often a component, were likely already in existence north of these aforementioned archaeological sites, prior to dates previously mentioned.

We can also track the trade in shea butter through records taken by explorers for many centuries; presented to Ibn Battuta, during his 1352-1353 travels [25], and Mungo Park recorded its widespread 
trade as he tracked the Niger River 1795-1797 [26]. After the Northern Territories were annexed to the Gold Coast, in early 1900, George Ekem Ferguson, a Fante geologist employed by the Gold Coast government to visit the north to find trading opportunities, recognized the abundance of the shea butter tree. However, at that time very few products that were produced locally were being traded outside of the north, with the exception of the shea butter that was going south in the Volta salt canoes [27]. In contrast, the southern part of the Gold Coast had a long tradition of export-oriented cash crops such as palm oil and cocoa. Thus, although these early explorers mentioned shea butter in their records, their focus was often on the expansion of access to palm oil. Experimentation with shea butter as a cash crop occurred in 1910 [28]. Most importantly, mounting evidence suggests that shea butter has been a human staple and traded across sub-Saharan Africa for many millennia, and although further verification is needed, it is proposed shea trade dates back at least to 4000-5000 years b.p.

\section{Twentieth Century Exports}

It is well documented that by the early 1900s, both French and British colonies began to export shea nuts and shea butter to Europe, where it could be used to produce margarine. In 1914, shea was traded at ten pounds sterling per ton in Liverpool. In fact, sheanuts were apparently sold at a loss due to the fact that an industrial mass market didn't exist for a commodity that was often considered a luxury in African markets outside of the area while it was primarily produced [28]. It wasn't until shea's use as an ingredient in chocolate that the existing price points began to make economic sense for the international shea trade.

Earliest records seen [29] for the development of cocoa butter alternatives show that research and development in this field had begun during the 19th century. According to records, palatable and stable cocoa butter substitutes (CBSs) had been developed by Messrs Loders and Nucoline Limited of Silvertown (UK) since 1887, resulting in a coconut fat based substitute named Nucoa. During the 1920s economic conditions were even more appealing in regards to creating cheaper chocolate ingredients.

By 1930 vegetable oil fractionation and formulation technology had continued to advance and Aarhus Oliefabrik was able to launch another CBS with the name CEBES ${ }^{\text {TM }}$ using coconut stearin and research continued on fractionated illipe fats [30]. However, it was not until the 1950s and 1960s that the first truly successful Cocoa Butter Equivalents (CBEs), using exotic stearin-rich fats, were first launched. By 1956 Unilever (UK) had developed and patented the CBE Coberine ${ }^{\mathrm{TM}}$ [31], subsequently Aarhus Oliefabrik (Denmark) launched Kewax in 1960, which was followed and replaced towards the of the 1960 s with a product known as Illexao ${ }^{\text {TM }}$ [32]. Modern equivalents of the aforementioned products Coberine and Illexao are now produced by successors of these firms, Loders Croklaan and AarhusKarlshamn (AAK), and are still used to present day.

The key importance of cocoa and shea sources of stearic acid is that they occur as symmetrical SOS, Tri-Acyl-Glycerols (TAGs) which have an exceptional melting curve perfect for sharing flavors with the human palate, which makes them vital ingredients in chocolates. Over time it has become a more significant material due to uncertainty in other sources of StOSt TAGs. Although difficult to process, due to the use of a wet-fractionation process involving acetone, available volumes were higher than other crops and additional processing costs and technology have deterred any competitors. 
After almost a century of international trade in sheanuts that even saw attempts to build and run processing plants in Mali and in Nigeria in the 1980s, the mid-late nineties saw a virtual collapse in the price of cocoa (Figure 1) and a corresponding loss of demand for specialty fats made from shea [33-37].

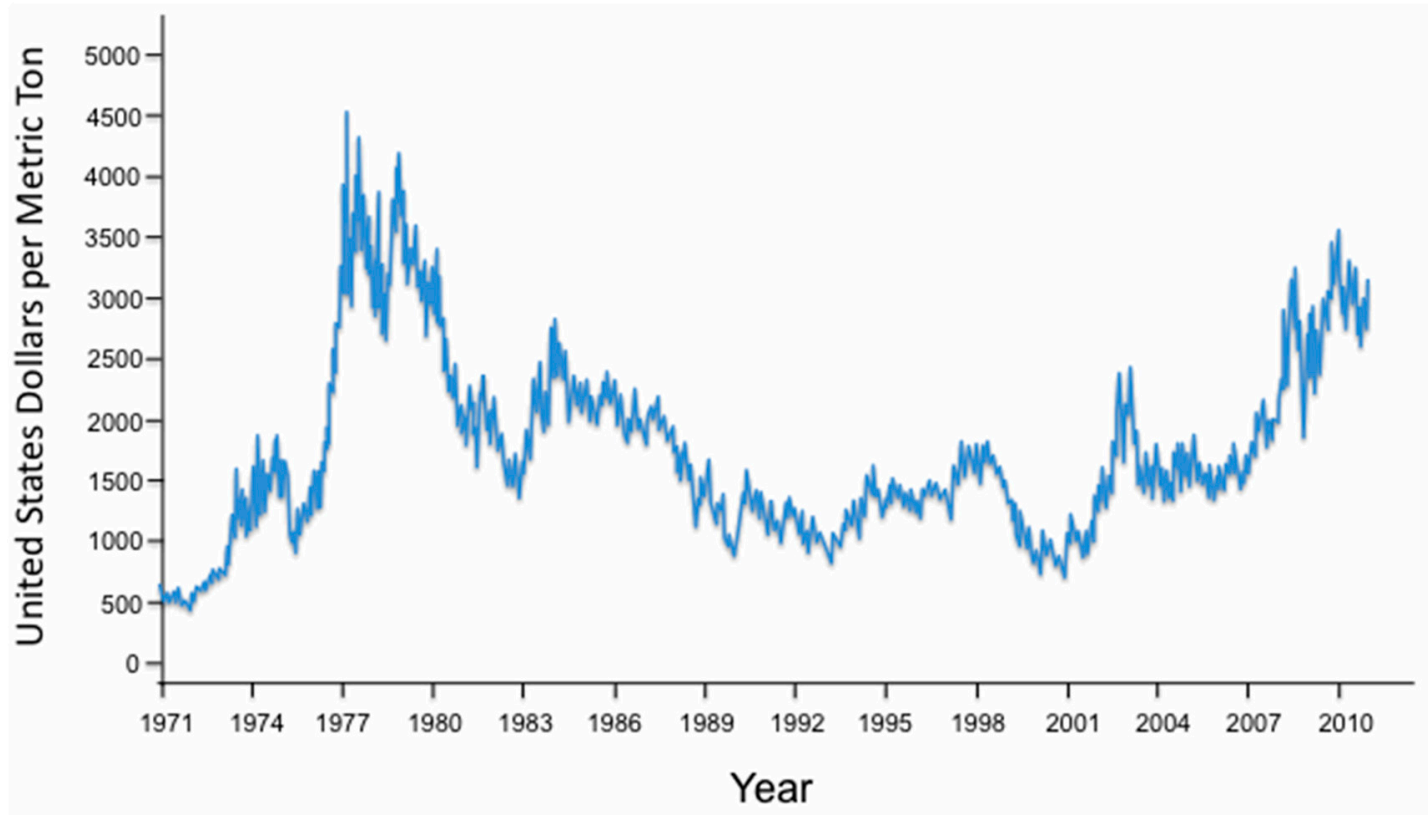

Figure 1. Four decades of international cocoa bean prices from Nasdaq [38].

With the rise of the petroleum industry, there was a reduced interest in bulk West African processing of cheap poor quality raw materials. Even Ghana's COCOBOD (Ghana's Cocoa Board) abandoned its regulation of the sector (though no national laws were changed) and turned over the Ghanaian shea industry to the private sector in 1992 [28].

By 2000 only a small oligopoly of firms, the convertors, were capable of mechanical extraction, shea fractionation and $\mathrm{CBE}$ formulation. However, various international donor, research and development organizations began to notice that vast numbers of the poorest of the poor, women collectors, were involved, that profits were rarely shared upstream and there was little private sector support for African shea production. There was a rapid increase of research on the shea sector and it soon became apparent that large volumes of low quality raw material existed across huge swathes of sub-Saharan African savannah. Sheanuts could then bought cheap, integrated sourcing strategies were strong, while fractionation and CBE formulation technologies were kept well-hidden. Handcrafted methods were criticized as inefficient and of poor production quality, while the low farm gate prices were blamed on poor quality and low demand vis-à-vis plentiful availability of supplies. The middlemen speculated for all they were worth, leaving the women pickers wondering whether it was even worth the effort to collect [28]. With such limited upstream development, opportunities for sustainable industry growth were limited and clearly under threat from various angles.

\section{Upstream Value Addition and African-Based Processing Plants}

Two important earlier drivers of the international trade in shea for cosmetic purposes have been L'Occitane, and The Body Shop. L'Occitane, and then The Body Shop's early attempts to source 
hand-crafted shea butter, directly from women in the $80 \mathrm{~s}$ and $90 \mathrm{~s}$ for the cosmetic sector were admirable. However, the hundreds of ton volumes of butter still being exported this aforementioned purpose are diminutive as compared to the hundreds of thousands of tons of sheanuts used in the edible sector, which then were still being sourced as unprocessed kernel [39]. Recent EU regulations allowed for the standardized addition of 5\% non-cocoa butter fats to finished products legally known as chocolate across Western Europe [37]. This aforementioned regulatory change, coupled with increasing concerns for the security of West African cocoa supplies, soon led to increased interest in the shea sector.

By 2001, shea butter export numbers began to increase (Figure 2) when a West African entrepreneur returned from abroad to set up a shea processing plant in north Ghana. With soft financing from one of the key convertors, a [now small] extraction plant—still sustainably crushing 12,000 SETs (Sheanut Equivalent Tons per annum-whether exported as nuts, butter, stearin or finished product) — was successfully built. The shea sector, coupled with growing support from researchers, NGOs and donors (most notably USAID and the EU) soon championed a series of successful projects focused on upstream supply chain stages with a vision to spotlight the millions of sheanut collecting women. During the following decade, plans to build and renovate larger shea extraction plants were soon realized and it is estimated that once all capacity is operational ( 23 plants in 7 countries), it will be possible to mechanically process the entire [current] West African export crop.

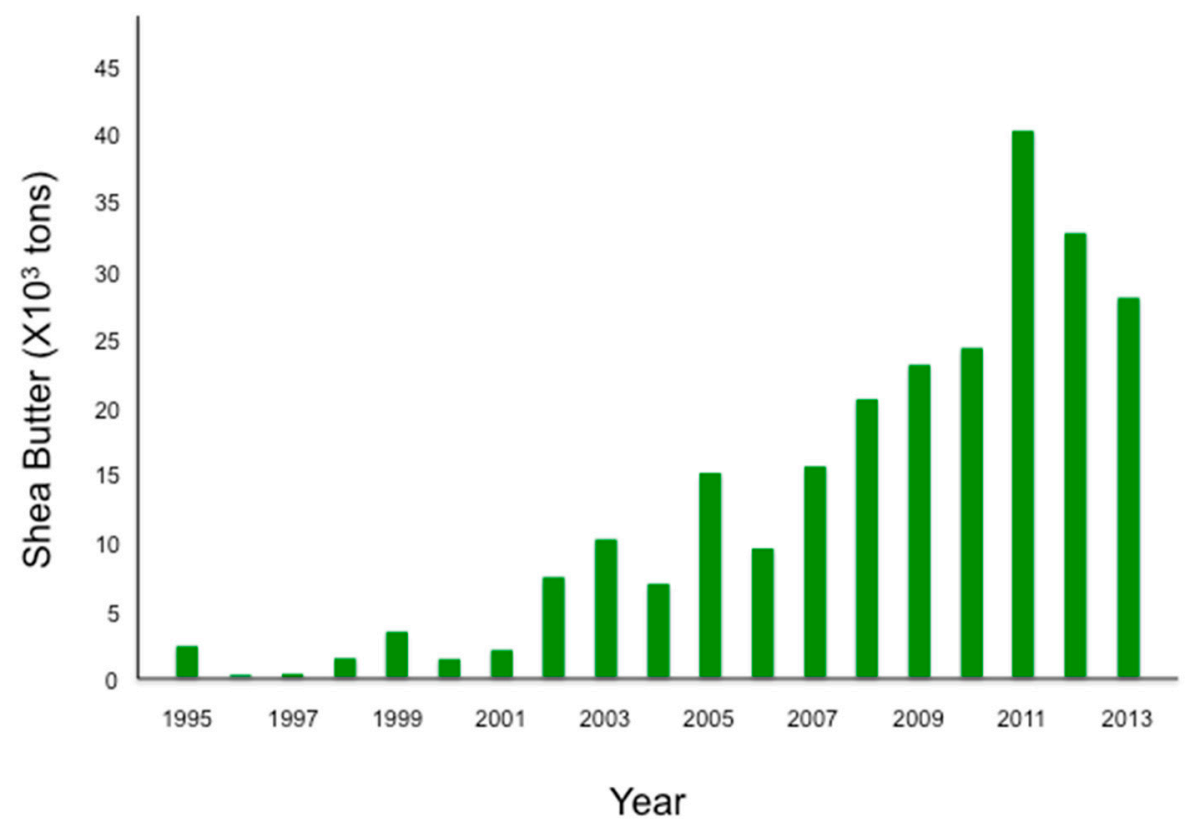

Figure 2. Shea butter exports from 1995 until 2013 (with permission from LMC International [39]).

\section{Changing Marketplace for Shea: From Women in the Field to International Requirements}

Liberalization of policies in agriculture in West Africa and the rise of some attractive goods for the West, which originate from West African countries, have increased the incentives for African women to concentrate on income generating activities at the beginning of existing and emerging value chains. Rural African women often specialize in locally appropriate agricultural activities; however, sometimes they also participate in other income generating activities where opportunities permit. 
Women often need to supplement their livelihoods and thus participate in these other activities, ranging from agricultural diversification to entrepreneurial activities in the marketplace. The commercialization of certain types of activities in West Africa, which includes the transformation of subsistence crops to final products (such as sheanuts that can be transformed into shea butter), have allowed women to participate in the local marketplace and generate extra income for the well-being of their households. Shea butter is used for subsistence and cash income, being important in both the local, and increasingly the international, marketplaces.

Over the past decade there has been an increasing demand for shea in the international marketplace, notably as an ingredient in chocolate confectionery and cosmetics [40]. This is because shea is known rich source of symmetrical Stearic-Oleic-Stearic Tri-Acyl-Glycerols (StOSt TAGs) and is now an important ingredient in the formulation of CBEs [41,42]. Quantifying volume aspects of shea's supply chain, however, is rather complex due to the use of crude and refined mechanical and hand-crafted butter, the shea cake or residue and the stearin, olein and bioactive fractions or derivatives in multiple sectors. It is currently estimated that between $10 \%-15 \%$ of all shea exports are destined for the cosmetic sector of which an estimated 15,000-25,000 SETs are hand-crafted and 150,000-250,000 SETs are mechanically crushed into butter within the Africa continent [39]. Although, prices, provided to women by the agro-food industry, are still low compared with the labor and time dedicated, their share of the export price has significantly increased over the last couple of decades. Women will preferentially maximize the time spent processing larger quantities of higher quality kernels; and using better quality nuts significantly improves extraction time and yields. On average, a north Ghanaian woman now processes a large sack of dry good quality shea kernels $(85-100 \mathrm{~kg})$ into $30-40 \mathrm{~kg}$ of butter whilst multi-tasking over a three day period. In the case of shea butter, one of the challenges for the shea value chain has been variability in the starting materials, which is directly influenced by how rural African women post-harvest process the nuts. How women process their sheanuts has often been in response to local market demands. However, as women are increasingly selling their processed nuts into value chains that ultimately feed into the international marketplace, they need to be responsive to different sets of demands.

\section{Shea Value Chain in the International Market}

Shea collection, post-harvest processing, butter extraction and the first stages of commercialization are still exclusively a female activity. The beginning of the shea value chain involves rural women collecting from the parklands and processing the nuts in their homesteads, before the derivative materials leave the continent, and on into the international marketplace, where the downstream shea is used as a mono-product or an ingredient in the multi-billion dollar cosmetic and food industries. As shea stearin (the high melting point fraction of shea butter) is usually cheaper than cocoa butter and an important functional ingredient when formulated into cocoa butter equivalents (Figure 3). It therefore, provides the opportunity to improve certain edible products and the European Union and other nations (excluding the USA) allow the use of shea and other non-cocoa butter fats as ingredients in products legally defined as chocolate [37]. This situation involves a profitable market for many actors in the sector chain, especially middlemen, exporters, importers, convertors and retailers who participate in the value-added product but rarely for the rural women who collect sheanuts or process the shea butter. 


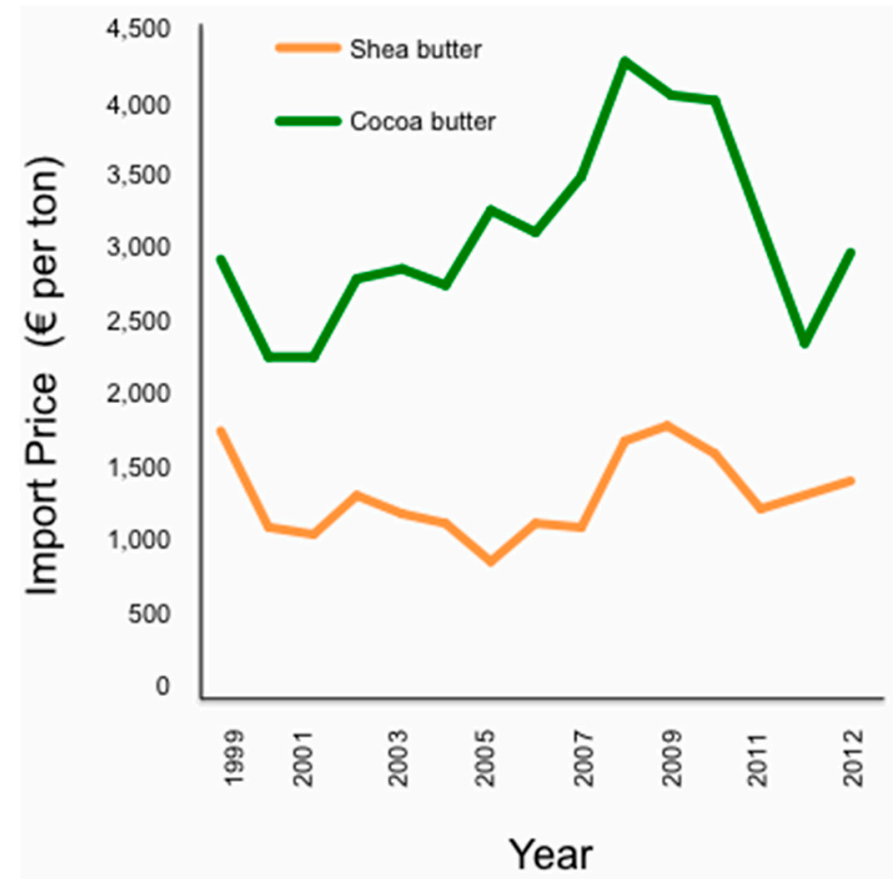

Figure 3. Import prices of shea and cocoa butter from 1999 to 2012 (with permission from LMC International [39]).

As discussed above and at various international forums on shea, there is a need to find a solution to the "Paradox of paradoxa"; a concept describing the fact that the majority of the global knowledge is on use of hand-crafted shea butter in cosmetics while the major of trade is in bulk sheanuts destined for industrial extraction (whatever the end market)-and ensure that benefits reach the women collectors of this crop. Export initiatives (e.g., socially responsible businesses designed to assist at the micro level at upstream locations in the supply chain) can help women, but large-scale traders often compete with the small players in the market (in this case the women) as the larger firms can benefit from economies of scale and have yet to truly achieve business conducted in a in a socially responsible or even transparent manner. It is possible, however, for informed women to collect, process and sell high quality sheanuts more directly, and at better prices, to middlemen or international buyers.

Shea is also consumed locally and adds to local economies in other ways. The average traditional consumption of shea kernels in Nigeria was estimated in 2004 around 80,000 metric tons per annum while the export as shea kernels were around 20,000 and the export as shea butter was effectively zero [6] (Figure 4). In many local diets, across the shea belt, the vegetable oil extracted from the kernel is the principal source of edible fat for people living in many rural communities [43,44]. Additionally, the wood from the shea tree is used as a high quality fuel wood and to make sturdy tools [45]. Finally, other crops are grown in shea parklands [46]. 


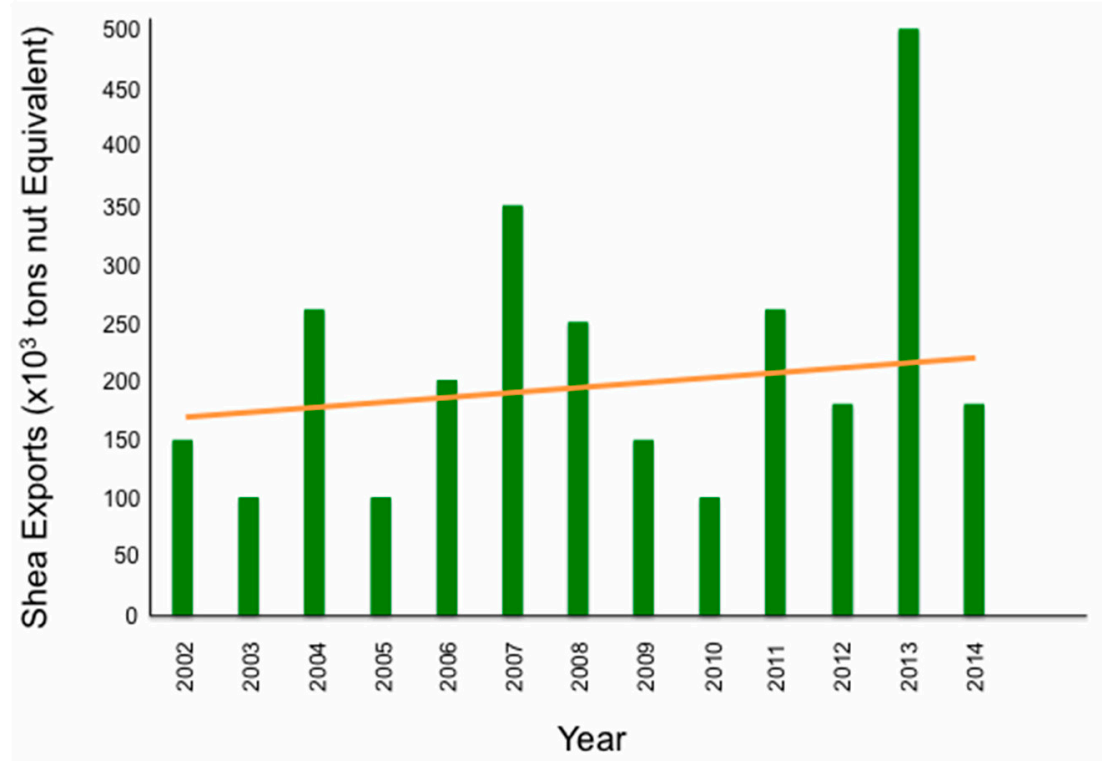

Figure 4. Shea exports in thousands of tons nut equivalent from 2002 to 2014 (with permission from LMC International [39]).

Recent estimates of the total export crop from the region, are as high as 500,000 SETs, sourced from just eight West African nations: Benin, Burkina Faso, Cote d'Ivoire, Ghana, Guinea-Conakry, Mali, Nigeria and Togo [38]. Although up from average annual exports of 170,000 tons a decade ago, the current annual average export is probably closer to 220,000 SETs due to poor harvests, e.g., when meeting contracts was threatened in 2005, 2009/2010, 2012 and 2014, or demand fluctuations.

Self-employed women working as producers of shea butter have the potential to be more formally linked into the global value chain. Increased participation of women in elevating the value of their shea products for the international shea value chain may ultimately help them to increase their incomes. However, there exist bottlenecks for women producing high quality nuts, and education is lacking on the best ways to process the nuts to optimize their physical properties for the international shea value chain. In this value chain, it is the proper processing of the nuts that is critical for the quality of final products and higher quality processed sheanuts are more sought after by those that export into the international marketplace [47].

According to Porter's Value Chain theory, profit margins are the value that is created and captured minus the cost of that value [48]. Porter also proposed that training (under resource management) represents a secondary activity [48] for firms even when all activities for the value chain are internalized within a company. In the case of shea, where shea nut production is externalized from the firms that trade in the shea nuts, there is even less of a link between investment in education and direct profits for the given firm that will trade and process the shea nuts (Table 1). Thus, educating women represents a collective good for the overall industry and not necessarily a direct input and benefit for a given company. There will be a need to develop educational strategies of public good for the deployment of R4D innovations for the initial steps of the shea value chain involving rural women. 
Table 1. Raw materials costs of shea, as well as the gross profit margin after material costs in terms of the percentage of the farm-gate nut prices.

\begin{tabular}{|c|c|c|c|c|c|c|c|}
\hline \multirow{2}{*}{$\begin{array}{c}\text { Farm gate cost } \\
\text { of sheanuts } \\
\text { per ton } \\
\\
-\end{array}$} & \multicolumn{3}{|c|}{$\begin{array}{l}\text { Raw material cost of sheanuts } \\
\text { (USD per ton of butter) }\end{array}$} & $\begin{array}{l}\text { Butter price paid } \\
\text { (e.g., } 3 \times \text { nut price } \\
+ \text { USD150 toll fee) } \\
\end{array}$ & \multicolumn{3}{|c|}{$\begin{array}{c}\text { Gross margin above raw } \\
\text { material cost } \\
\text { (\% of farm-gate nut price) }\end{array}$} \\
\hline & \multicolumn{3}{|c|}{ By dry weight extraction rate } & - & \multicolumn{3}{|c|}{ By dry weight extraction rate } \\
\hline- & $29 \%$ & $32 \%$ & $35 \%$ & - & $29 \%$ & $32 \%$ & $35 \%$ \\
\hline$\$ 100.00$ & $\$ 344.83$ & $\$ 312.50$ & $\$ 285.71$ & $\$ 450.00$ & $31 \%$ & $44 \%$ & $58 \%$ \\
\hline$\$ 150.00$ & $\$ 517.24$ & $\$ 468.75$ & $\$ 428.57$ & $\$ 600.00$ & $16 \%$ & $28 \%$ & $40 \%$ \\
\hline$\$ 250.00$ & $\$ 862.07$ & $\$ 781.25$ & $\$ 714.29$ & $\$ 900.00$ & $4 \%$ & $15 \%$ & $26 \%$ \\
\hline$\$ 300.00$ & $\$ 1034.48$ & $\$ 937.50$ & $\$ 857.14$ & $\$ 1050.00$ & $1 \%$ & $12 \%$ & $23 \%$ \\
\hline$\$ 350.00$ & $\$ 1206.90$ & $\$ 1093.75$ & $\$ 1000.00$ & $\$ 1200.00$ & $-1 \%$ & $10 \%$ & $20 \%$ \\
\hline$\$ 400.00$ & $\$ 1379.31$ & $\$ 1250.00$ & $\$ 1142.86$ & $\$ 1350.00$ & $-2 \%$ & $8 \%$ & $18 \%$ \\
\hline$\$ 450.00$ & $\$ 1551.72$ & $\$ 1406.25$ & $\$ 1285.71$ & $\$ 1500.00$ & $-3 \%$ & $7 \%$ & $17 \%$ \\
\hline
\end{tabular}

Women need information about best practices for storage if they are not going to process the nuts right away. They also need information about fair market prices at which to sell the kernels or the processed shea butter in the local markets, or to agents or international traders. Thus, there are opportunities for the development of educational materials appropriate for these women who are at the beginning of the value chain.

Mechanisms to deliver market information and educational content that can positively impact this first step in the value chain has significant potential to increase the value of shea, potentially increasing the quality of the initial product, and hence increasing its value, and possibility instilling the concept that quality control and delivery of a consistent product has higher marker value for those further along the value chain.

Other aspects, which could be addressed in the value chain of shea, include education on how to improve resource sustainability, e.g., protect saplings, plant shea from seed, graft scions from superior varieties, or provide information on business skills and marketplace literacy that will inform women of financial opportunities for them in the initial part of the value chain.

\section{Gender Challenges and Impact on Sector Sustainability}

The participation of women in the international market could increase the value of their products and their labor. Besides developing methods that can improve access to information and knowledge, there are other concerns regarding gender issues in the participation of women in the international market. The increase of economic value in the shea butter industry through value addition at source for international exportation, and therefore access by women to the formal sector, could potentially threaten the role of women in the industry because men may preferentially want to control exported commodities. For instance, Greig [49] states that in Burkina Faso, men are more likely to control commodities that are connected to the international market while women are expected to participate in 
small-scale production in the local market. When the value of the product export increases, men often assert control of the associated profits while women are still in charge with the processing and other labor-intensive aspects of the commodity [50]. Thus, in order for a married woman to participate in a commercial activity her husband needs to approve of it [51]. There are other assumptions made in the profit of the shea butter processing. Elias and Carney [52] argue that with commercialization of sheanuts women face more economic changes in their local environment due primarily to two factors: (i) women are sometimes forced to share revenues with male households and (ii) with the decline of other export crops, young men are competing with women to collect the nuts. In the case of the shea butter industry, women could still process the nuts through intensive labor and could participate in the international market but ultimately men might gain control over the profits. This situation could damage the extent of women's involvement in the shea butter value chain and deepen the gaps in income in the shea commodity chain.

Globalization efforts have the potential to include recognition of female shea communities supporting women roles in control of labor and earnings in shea processing. This is where women-focused educational materials on marketplace literacy might ultimately be used to help women develop strategies to deal with these gender-specific economic shifts, however, if this approach were to be taken then, the content of such materials will have to be carefully developed and evaluated in further research studies. This represents a far more complex set of issues that go beyond the technique-driven educational approaches.

One alternative for women to address some of these gender constraints is for women to organize themselves in cooperatives to avoid and confront gender inequities; developing educational strategies, to be shared amongst women's groups, that help women to achieve this goal is laudable, but it still remains an important unknown that needs to be addressed in a proactive manner. Furthermore, there is certainly a concern regarding how increased international pressure to produce and export shea butter might result in loses, regarding their knowledge and cultural heritage, potentially relegating them to the passenger seat instead of the driving force of the shea butter industry.

Finally, from a gender perspective, the role of women and men needs to be carefully considered in terms of sector sustainability. For example, what are the gender roles in promoting parkland and shea tree protection vis-à-vis development of more mechanically cultivated agricultural systems, and encouraging involvement (of younger women and men) and investments (into village processing centers or urban factories) according to who perceives the increased benefits from sales of sheanuts and butter?

\section{Challenges from Local to International Markets: R4D Opportunities for Women to Produce High Quality Shea for International Markets}

The processing of shea butter can be considered as a personal, and at the same time a collective female activity. Women collect nuts on their own, from fallows or their husbands' farms, and carry them to their own compounds to process into dry kernels individually (rarely sharing labor at the boiling and drying stages). These stages give them ownership of the sheanuts. When they process the nuts into butter for export, women are more likely to operate in a more collective manner-sharing tasks like water and firewood collection, crushing, roasting, milling and kneading when producing shea for sale, often as members of organized cooperatives. Very poor women (with fewer income 
opportunities) tend to sell the kernels, immediately after harvesting and post-harvest processing, often at the lowest market prices, in order to buy what is necessary for the agricultural season. Other women store the nuts and sell or process them into butter at a later time. Women's income from shea kernels and shea butter is used to buy other goods such as food, clothing, and medicine, and to invest in their children's schooling [50]. Female contributions to household income empower women, giving them more influence and preferences over expenditures.

When women extract butter from sheanuts, they are able to generate more local value-addition than they for the unprocessed kernels. When sheanuts are processed into butter, there are, however, still many information gaps for these women. For example, more information is required on the quality standards demanded in the international market place, what packaging opportunities exist, how can their direct access to finance be facilitated, are there options to route their products through tollrefineries and what can be done to command a better price more in line with the women's inputs in terms of time, labor and other valuable resources. Moreover, the fear for small players like women working in the shea butter industry is that foreign direct investment (FDI) gains control of processing facilities; displacing women engaged in processing nuts, reducing the value of their cultural skills and traditional knowledge in shea butter processing. This latter issue suggests the need for guidance on the organizational skills required to form structures more able to better negotiate terms with international buyers and investors.

In the international marketplace, there are a number of factors that can impact the value of shea butter for those that use this material in food and cosmetics: (i) high levels of free fatty acids (FFA); the breakdown products following hydrolysis of Tri-Acyl-Glycerols (TAGs), which have to be removed during refining in order to standardize the product and increase shelf-life, result in approximately $1.5 \%$ loss in butter volume for every $1 \%$ of FFA removed; (ii) the carcinogenic Polycyclic Aromatic Hydrocarbons (PAHs) [53] which must be completely removed during the refining process prior to any edible use in the USA or EU markets; (iii) high levels of volatile peroxides which also need to be removed through refining steps as these products of oxidation can further catalyze additional degradation of a stored product, again reducing shelf-life; and, (iv) removal of any water, contaminants or other impurities (which impact shelf-life and standard formulations) will also result in loss of butter volumes during refining.

High levels of FFAs occur because women allow the nuts to sit for too long before processing them, and as the sheanuts germinate, metabolic enzymes (lipases) hydrolyze shea TAGs into mono- and di-glyceride FFAs. Increased FFA levels can additionally result following poor storage and infestation by fungi or molds as these micro-organisms will also metabolize the vegetable oils and fats [54]. Smoking of the nuts results in a coating of aromatic hydrocarbons compounds released from the burning firewood. These are regulated in the international edible marketplace. Finally, if the nuts are over-heated (boiled) for too long, it is assumed enzymes that form protective anti-oxidant complexes are denatured and peroxides levels increase in the final product following oxidation as a result [47].

Recent collaborative research has resulted in a set of recommendations for a simple process by which women can boil and sundry the nuts, such that the levels of all of the negative, aforementioned, factors are minimized in the nut, resulting in the opportunity to more easily extract better yields of a higher quality product. Additionally, this new approach reduces the amount of firewood and water that are required to process the sheanuts. Essentially, women need to collect the nuts from the ground 
within one week of when the nuts have dropped from the tree and, instead of storing them for weeks, boil them for at least $15 \mathrm{~min}$ but less than $40 \mathrm{~min}$ (denaturing smaller nuts takes less time), and then sundry the nuts until their moisture levels drop enough that the kernels are no longer soft; i.e., they are hard when pinched. Louppe [54] recommends that the lipolytic activity of the seed lipases and microorganisms is halted by heating, and desiccating to a moisture content lower than $8 \%$. Thus, educating these women in this improved processing technique becomes a logical step in the value chain where education can potentially result in increased income for those at the beginning of a value chain as it reduces resource use (labor, firewood and water), improving sustainability of a growing sector whilst increases availability of high quality raw materials for stakeholders later in the value chain [55].

Shea represents a challenging value chain, especially as the first steps are in the hands of difficult to reach, poorly educated rural women, who have diverse cultural backgrounds and are scattered across the vast shea belt from the far west of the African Sahel-Savannah, e.g., Gambia and Senegal, to the far east of this vegetation region, e.g., Ethiopia, South Sudan and Uganda (a 3-4 million $\mathrm{km}^{2}$ zone) [56]. However, what they do have in common is that their initial product (the shea nuts) either moves to traders in the next step of the value chain or it is passed into a handcrafted value chain (Figure 5) [57,58]. The recommendations developed to improve upon current post-harvesting practices, important for both aforementioned aspects of this value chain, are relatively simple: immerse in boiling water for a short period (15-40 min), as soon after collecting un-germinated mature fruit as possible, sun-dry efficiently (with rapid de-husking) and store in jute sacks in clean, dry aerated conditions. Adherence to these simple guidelines results in significant quality improvement, gains that have the potential to attract premium prices when bulk volumes of nuts, having oil content above $45 \%$ and FFAs below $4 \%$, become available to international traders [57]. Adoption of such improved sheanut processing methods will also result in potentially significant environmental benefits and production footprint, i.e., reduced use of firewood and water through easier extraction of higher yields with less wastage and labor requirements. This improved sheanut processing strategy is a result of recent for R4D outcomes.

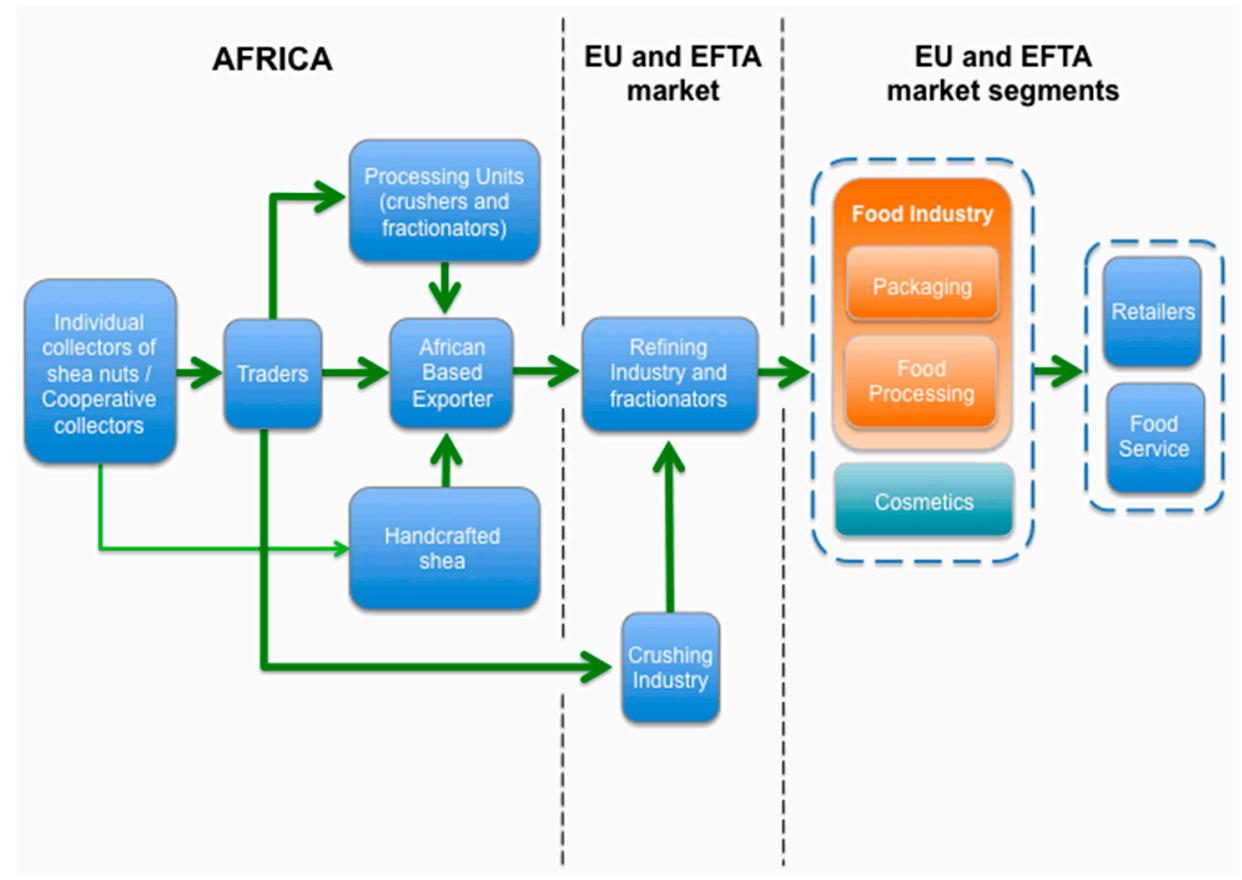

Figure 5. Structure of the shea supply chain from Africa to EU markets (with permission from CBI [58]). 


\section{Potential of ICT Use to Enable Empowerment of Women in a Shea Value Chain}

Developing educational content that women shea producers can access and that can be taken across language groups and cultural boundaries of Africa, in an economically viable manner, has been a serious challenge for numerous develop projects. Evidence suggests that finding educational content appropriate for low literate groups of individuals that speak diverse languages, across many cultural boundaries, is a challenge. Furthermore, the ability to take research R4D innovations into the hands of people that can use the knowledge has proven to be a significant challenge especially in programs, which lack large amounts of deployment/extension funding. How does one attempt to share even the most basic information with millions of women who are highly intelligent, but illiterate, and culturally extremely diverse from one another? The challenge exists of how to educate women in any given improved technique, when they live across so many different countries, speak divergent languages, are often low literate learners, and many of them live in difficult to reach rural villages.

Scientific Animations Without Borders (SAWBO) is a University of Illinois based program that creates educational content from experts in the form of short animated videos [59], the animations can be placed in any language, and all animations are given out freely to anyone wishing to use them in educational programs. Briefly, SAWBO takes recommendations for improved processes, animates these in a simple understandable manner, with as few cultural and religious connotations as possible, then develops appropriate scripts and translate these into voice overlays in whichever language is culturally appropriate for the given target groups. SAWBO has been developing approaches to try to alleviate the problem of taking R4D innovations into the field in a cost effective manner in local languages without the need for literacy. Thus, educational materials, for processing steps that increase the quality of shea early in the value chain, can be developed by SAWBO based on R4D innovations.

Although SAWBO creates and deploys this content virtually, it is the domain of local groups to develop strategies and approaches for on-the-ground meaningful impact. Development and deployment of such content requires a "pull and push" system. In terms of "pull", SAWBO animations are first created based on R4D innovations in collaboration with R4D groups, i.e., following demand expressed by working groups of industry associations. Voice can then be overlaid through virtual online collaborations with whichever language group is required from around the world. This allows SAWBO the opportunity to create verified R4D approaches and create content that can then be made available in numerous languages.

On the "push" side of the equation, SAWBO has multiple approaches to deliver content. All videos can also be downloaded through both of SAWBO's websites, a full version and a mobile version (for people with low bandwidth) or through the online system known as the "Sustainable Development Knowledge Interface" (SusDeViKI) [59-62]. Thus, for development groups, that wish to use these videos in their educational programs, they can easily access the necessary content from the Internet for deployment into the field on cell phones. The videos themselves can be viewed on cell phones and transferred to cell phones in the village using Bluetooth ${ }^{\circledR}$ or other wireless technology. The potential for use of Apps such as Whatsapp and Viber in disseminating educational tools also needs to be explored. SAWBO also works with networks of people within organizations focused on a given issue (where content has been developed) in order to make their membership aware of the content and instruct them on how to download and use such content in their extension programs. Educational 
programs such as SAWBO exemplify the need to have a system that can deliver information in local languages. Research information appropriate for women in local languages about sheanut post-harvest processing and storage, and butter extraction methods can then be accessed by those wishing to upon locally used methods with the result that a better and more valuable product is available for those downstream in the international value chain.

Women working individually in the informal sector in rural areas and without access to information about opportunities in the international market depend on middlemen and final retailers that could take advantage of their situation. Thus, it is possible that videos (such as SAWBO animations) could be used in educational programs for local women's cooperatives to gain access to the required information that would facilitate their negotiation ability on their shea products (i.e., marketplace literacy-based content). One opportunity, for women to organize themselves in cooperatives, is to buy and share technology that could facilitate an understanding of what product parameters would give their products more access to international markets and potentially help them to gain higher prices for the final product. Carr et al. [63], suggested that women as members of associations would also allow them to have links to marketing and new information through information and communication technology. Thus, associations and cooperatives might be logical routes to disseminate such educational videos.

SAWBO represents a project that is positioned to help individual women producers and producer associations with information and knowledge about better practices in shea butter production to bargain for better prices in the marketing chain locally and internationally, e.g., guidelines to develop straightforward memorandums of understanding with exporters and other partners that can strengthen negotiation options. Access to research information that could improve the quality of shea butter might also strengthen their ability to obtain improved access to finance, in their propensity to invest in technology and other economic resources that can help them cope with the demands of the international markets.

\section{Conclusions}

In this paper, having contextualized shea utilization both historically and in the modern-day edible and personal care sectors, the critical bottlenecks that occur in the upstream levels of the shea value chain are then identified. We have outlined that local value addition; through improved sheanut quality and through lower resource use, and hence more sustainable, village-based shea butter processing, should increase opportunities for rural women to alleviate poverty whilst simultaneously reducing environmental impact. The shea industry is steadily increasing its potential to locally and internationally empower women in rural areas of Africa, through culturally sustainable approaches that encourage parkland protection, efficient resource use and upstream value addition. Educational programs should help to locate and address the different gaps and motivate processors to ensure better quality to meet international demands while at the same time position themselves to control the increase returns for their labor and knowledge. Bello-Bravo and Baoua [62] observed that when showing SAWBO videos in Niger, those that observed these videos often talked at length about other education needs in their community. Thus, such educational tools also represent a potential two-way dialogue where ideas from the field (such as indigenous knowledge) can be incorporated into additional educational animations and then used in future educational programs [61]. 
Ultimately, since shea is a traditional gender-selective crop it has the potential to provide value addition for women and the means to improve their livelihoods resulting in the promotion of rural development. A first logical step would be to determine the effectiveness of this approach in educational programs targeted at educating women on improved processing techniques, such as best practices for enhancing sheanut and shea butter quality, as well exploring the possibility of using the SAWBO education approach in marketplace literacy-based educational programs to assist women in capitalizing on increased economic opportunities that may come with the changing nature of the shea industry. Additionally, future efforts will need to take into consideration how such efforts may impact women in different countries, regions, cultural or language groups or even in terms of geographic proximity to other players in the value chain of shea or in terms of trade routes. Ultimately, if both forms of educational materials can be demonstrated to positively impact women of the shea value chain economically, then the fact that such ICT approaches have potential for scalability; such a strategy might hold out the hope of cost-effectively and sustainably addressing the "Paradox of paradoxa".

\section{Acknowledgments}

Thank you to the women collectors of shea, staff of the Savannah Fruits Company and the secretariat of The Global Shea Alliance, without whom the opportunity to develop this paper could not have been realized. The pages charges for this paper were paid for by funds provided to JBB and BRP from the ADM Institute for the Prevention of Postharvest Loss at University of Illinois.

\section{Author Contributions}

All authors contributed equally to the development of this paper. The majority of shea industry background has come from PNL and the majority of the background on ICT and R4D has come from JBB and BRP. Production of the animation, along with synthesis and development of the win-cubed approach to solving shea's quality issues, were team efforts. All authors read and approved the final manuscript.

\section{Conflicts of Interest}

The authors declare no conflict of interest. PNL works in the shea industry as a consultant and trader, but has no conflict of interest with this article as it aims to offer solutions to upstream issues in a pre-competitive manner.

\section{References}

1. Rousseau, K.; Gautier, D.; Wardell, D.A. Coping with the upheavals of globalization in the shea value chain: The maintenance and relevance of upstream shea nut supply chain organization in western Burkina Faso. World Dev. 2015, 66, 413-427.

2. Lovett, P.N. Sourcing Shea Butter in 2010: A Sustainability Check. In Global Ingredients and Formulation Guide 2010 The Green Book of Cosmetics; Verlag für chemische Industrie, H. Ziolkowsky GmbH: Augsburg, Germany. 2010; pp. 62-68. 
3. Fontaine, C.; Lovett, P.N.; Sanou, H.; Maley, J.; Bouvet, J.-M. Genetic diversity of the shea tree (Vitellaria paradoxa C.F. Gaertn), detected by RAPD \& chloroplast microsatellite markers. Heredity 2004, 93, 639-648.

4. Boffa, J.M. Agroforestry Parkland Systems in Sub-Saharan Africa: FAO Conservation Guide 34. Available online: http://www.fao.org/docrep/005/x3940e/x3940e00.htm (accessed on 3 May 2013).

5. Hall, J.; Aebischer, D.; Tomlinson, H.; Osei-Amaning, E.; Hindle, J. Vitellaria paradoxa: A monograph. In School of Agriculture and Forest Sciences; University of Wales: Bangor, UK, 1996.

6. Lovett, P.N. Technical Report No. 2. In The Shea Butter Value Chain: Production, Transformation and Marketing in West Africa; West Africa Trade Hub: Accra, Ghana, 2004.

7. Lovett, P.N.; Haq, N. Evidence for anthropic selection of the Sheanut tree (Vitellaria paradoxa). Agrofor. Syst. 2000, 48, 273-288.

8. Maranz, S.; Wiesman, Z. Evidence for indigenous selection and distribution of the shea tree, Vitellaria paradoxa, and its potential significance to prevailing parkland. J. Biogeogr. 2003, 30, 1505-1516.

9. Harlan, J.R. Crops and Man, 2nd ed.; American Society of Agronomy-Crop Science Society: Madison, WI, USA, 1992.

10. Harlan, J.R. Agricultural origins: Centers and noncenters. Science 1971, 174, 468-474.

11. Lamien, N.; Ouédraogo, S.J.; Diallo, O.B.; Guinko, S. Productivité fruitière du karité (Vitellaria paradoxa Gaertn. C.F., Sapotaceae) dans les parcs agroforestiers traditionnels au Burkina Faso. Fruits 2004, 59, 423-429.

12. Houehanou, T.D.; Kindomihou, V.; Stevart, T.; Tente, B.; Houinato, M.; Sinsin, B. Variation of Loranthaceae impact on Vitellaria paradoxa C.F. Gaertn. fruit yield in contrasting habitats and implications for its conservation. Fruits 2013, 68, 109-120.

13. Kristensen, M.; Lykke, A. Informant-based valuation of use and conservation preferences of savanna tress in Burkina Faso. Econ. Bot. 2003, 57, 203-217.

14. Sanou, H.; Picard, N.; Lovett, P.N.; Dembélé, M.; Korbo, A.; Diarisso, D.; Bouvet, J.-M. Phenotypic variation of agromorphological traits of the shea tree, Vitellaria paradoxa C.F. Gaertn., in Mali. Genet. Resour. Crop Evol. 2006, 53, 145-161.

15. Sanou, S.; Kambou, S.; Teklehaimanot, Z.; Dembélé, M.; Yossi, H.; Sina, S.; Djingdia, L.; Bouvet, J.M. Vegetative propagation of Vitellaria paradoxa by grafting. Agrofor. Syst. 2004, 60, 93-99.

16. Yeboah, J.; Lowor, S.T.; Amoah, F.M.; Owusu-Ansah, F. Propagating structures and some factors that affect the rooting performance of shea (Vitellaria paradoxa Gaertn.) stem cuttings. Agric. Biol. J. N. Am. 2011, 2, 258-269.

17. Chimsah, F.A. The act of propagating shea. Available online: http://www.globalshea.com/uploads/ files/conference_presentations/chimsah_francis_uds-ghana_the_act_of_propagating_shea_41.pdf (accessed 15 December 2014).

18. Lovett, P.N.; Haq, N. Progress in developing in vitro systems for shea tree (Vitellaria paradoxa C.F. Gaertn.) propagation. For. Trees Livelih. 2013, 22, 60-69.

19. Wicker, F.D.P. The Road to Punt. Geogr. J. 1998, 164, 155-167. 
20. Louvre, P.N. Accédez en ligne à l'ensemble des œuvres du Louvre. Available online: http://www.louvre.fr/moteur-de-recherche-oeuvres?f_search_art=karite (accessed on 1 December 2014). (In French)

21. McCreesh, N.C.; Gize, A.P.; David, A.R. Ancient Egyptian hair gel: New insight into ancient Egyptian mummification procedures through chemical analysis. J. Archaeol. Sci. 2011, $38,3432-3434$.

22. Neumann, K.; Kahlheber, S.; Uebel, D. Remains of woody plants from Saouga, a medieval west African village. Veget. Hist. Archaeobot. 1998, 7, 57-77.

23. Kahlheber, S. Indications for agroforestry; archaeobotanical remains of crops and woody plants from medieval Saouga, Burkina Faso. In The exploitation of Plant Resources in Ancient Africa; van der Veen, M., Ed.; Kluwer/Plenum: New York, NY, USA, 1999; pp. 89-100.

24. Höhn, A.K.; Neumann, K. Shifting cultivation and cultural landscape development during the Iron Age (0-1500 AD) in the Sahel of Burkina Faso, West Africa-Insights from archaeological charcoal. Quat. Int. 2012, 249, 72-83.

25. Dunn, R.E. The Adventures of Ibn Battuta, a Muslim Traveler of the Fourteenth Century; University of California Press: Oakland, CA, USA, 1986; p. 357.

26. Park, M. Travels into the interior districts of Africa performed under the direction and patronage of the African Association in the years 1795, 1796 and 1797. In Travels into the Interior of Africa; Swift, J., Ed.; Eland Publishing: London, UK, 1983; pp. 1-264.

27. Sutton, I. Colonial agricultural policy: The non-development of the Northern Territories of the Gold Coast. Internat J. Afr. Hist. Stud. 1989, 22, 637-669.

28. Chalfin, B. Shea Butter Republic: State Power, Global Markets, and The Making Of An Indigenous Commodity; Routledge: London, UK, 2004; p. 320.

29. The Straits Times 18 November 1902. Butter Substitutes. Available online: http://eresources.nlb.gov. sg/newspapers/Digitised/Article/straitstimes19021118.2.4.aspx (accessed on 28 November 2014).

30. Martin, S.M. The UP Saga; NIAS Press: Copenhagen, Denmark, 2003.

31. Best, R.L.; Crossley A.; Paul S.; Pardu H.; Soeters, C.J. GB Patent 827172, 1956.

32. Grant, T. International Directory of Company Histories; St. James Press: Detroit, MI, USA, 2005; Volume 68.

33. Fold, N. Restructuring of the European chocolate industry and its impact on cocoa production in West Africa. J. Econ Geograp. 2001, 1, 405-420.

34. Andrews, E. Great Chocolate War Reveals Dark Side of Europe. New York Times, 24 October 1997, p. A3.

35. McNeil, D. Britain's sweet victory: Europe accepts candy. New York Times, 16 March 2000, p. A4.

36. Morrison, R. Send in the Chocolate Soldiers. The Times, 23 February 2000.

37. Timms, R.; Berger, K. Chocolate, chocolate fats and the EU chocolate directive. J. Sci. Food Agric. 2003, 83, 1539-1540.

38. Nasdaq. Cocoa: Latest Price \& Chart for Cocoa. Available online: http://www.nasdaq.com/ markets/cocoa.aspx?timeframe=45y (accessed 1 December 2014). 
39. LMC International. Alternatives to Cocoa Butter: The Outlook for CBEs, CBSs and Exotic Fats. Available online: https://www.lmc.co.uk/Cocoa-Alternatives_to_Cocoa_Butter_The_outlook_ for_CBEs_CBSs_and_exotic_fats (accessed 1 December 2014).

40. Alander, J. Shea Butter-A Multifunctional Ingredient for Food and Cosmetics. Lipid Technol. 2004, 16, 202-205.

41. Loh Moong Ming, H. Specialty fats-How food manufacturers can get more out of them. Lipid Technol. 2008, 20, 35-39.

42. Talbot, G.; Slager, H. Cocoa butter equivalents and improvers: Their use in chocolate and chocolate-coated confectionery. Focus on Chocolate. Agro Food Ind. Hi-Tec. 2008, 19, $28-29$.

43. Saul, M.; Ouadba, J.; Bognounou, O. The wild vegetation cover of Western Burkina Faso colonial policy \& post-colonial development. In African Savannas: Global Narratives \& Local Knowledge of Environmental Change; Basset, T., Crummey, D., Eds.; Heinemann: Portsmouth, NH, USA, 2003; pp. 121-160.

44. Fleury, J.M. The Butter Tree. IDRC Rep. 1981, 10, 6-9.

45. Booth, F.; Wickens, G. Non-Timber Uses of Selected Arid Zone Trees and Shrubs in Africa: FAO Conservation Guide 19; Food and Agriculture Organization of the United Nations: Rome, Italy, 1998.

46. Boffa, J.M.; Taonda, S.; Dickey, J.; Knudson, D. Field-scale influence of karité (Vitellaria paradoxa) on sorghum production in the Sudan zone of Burkina Faso. Agrofor. Syst. 2000, 49, $153-175$.

47. Vind, J.; Lovett, P.N. Effects of boiling freshly-harvested sheanuts (Vitellaria paradoxa C.F. Gaertn.) on butter quality: Case study from north Ghana. 2015, unpublished work.

48. Porter, M. Competitive Advantage_Creating and Sustaining Superior Performance; Free Press: New York, NY, USA, 1985.

49. Greig, D. Shea Butter: Connecting Rural Burkinabè Women to International Markets through Fair Trade. Dev. Pract. 2006, 16, 465-475.

50. Pouliot, M. Contribution of "women's gold" to West African Livelihoods: The case of shea (Vitellaria paradoxa) in Burkina Faso. Econ. Bot. 2012, 66, 237-248.

51. Saul, M. Separateness and Relation: Autonomous Income and Negotiation among Rural Bobo Women. In The Household Economy: Reconsidering the Domestic Mode of Production; Wilk, R., Ed.; Westview Press: Boulder, CO, USA, 1989; pp. 179-193.

52. Elias, M.; Carney, J.A. A Feminized Subsidy from Nature. Afr. J. Int. Afr. Inst. 2007, 77, 37-62.

53. Commission Regulation (EU) No 835/2011 of 19 August 2011 amending Regulation (EC) No $1881 / 2006$ as regards maximum levels for polycyclic aromatic hydrocarbons in foodstuffs. Available online: http://eur-lex.europa.eu/legal-content/EN/TXT/PDF/?uri=CELEX:32011R0835\& from=EN (accessed on 28 May 2013).

54. Louppe, D. Projet de Promotion et de Developpement des Exportations Agricoles (PPDEA), Composante Recherche-Développement; CIRAD-Forêt: Le karité en Côte d'Ivoire, France, 1994; p. 29. (In French)

55. Womeni, H.M.; Ndjouenkeu, R.; Kapseu, C.; Mbiapo, F.T.; Parmentier, M.; Fanni, J. Effet de la Cuisson et du Séchage des noix de karité (Butyrospermum parki (G.Don) Kotchy) sur la qualité du beurre. Tropicultura 2006, 24, 175-182. 
56. Naughton, C.C.; Lovett, P.N.; Mihelcic, J.R. Land Suitability Modeling of Shea (Vitellaria paradoxa) Distribution across Sub-Saharan Africa. Appl. Geogr. 2015, 58, 217-227.

57. Global Shea Alliance. Industrial quality standards for shea kernel. 2013. Available online: http://www.globalshea.com/uploads/files/shea_2014_the_industry_unites_conference_documents/ quality_standards_196.pdf(accessed on 14th August 2014).

58. CBI Ministry of Foreign Affairs. CBI Product Factsheet: Shea Butter in the EU and EFTA. Available online: http://www.cbi.eu/sites/default/files/study/product-factsheet-shea-butter-europevegetable-oils-oilseeds-2014.pdf (accessed on 15 August 2014).

59. Bello-Bravo, J.; Seufferheld, F.; Steele, L.D.; Agunbiade, T.; Guillot, D.; Cutz, G.; Pittendrigh, B.R. Scientific Animations Without Borders: An international online approach for building applicable scientific educational materials for use on cell phones and the Internet in developing nations. Int. J. Sci. Soc. 2011, 2, 49-62.

60. Bello-Bravo, J.; Diaz, R.; Venogupal, S.; Viswanathan, M.; Pittendrigh, B. Expanding the impact of practical scientific concepts in developing nations through an inclusive and participatory virtual knowledge ecosystem. J. World Univ. Forum 2010, 3, 147-164.

61. Bello-Bravo, J.; Pittendrigh, B. Scientific Animations without Borders: A new approach to capture, preserve and share indigenous knowledge. J. World Univ. Forum 2012, 5, 11-20.

62. Bello-Bravo, J.; Baoua, I. Animated Videos as a Learning Tool in Developing Nations: A Pilot Study of Three Animations in Maradi and Surrounding Areas in Niger. Electr. J. Info Syst. Dev. Countr. 2012, 55, 1-12.

63. Carr, M.; Chen, M.A.; Tate, J. Globalization and Home-Based Workers. Femin. Econ. 2000, 6, $123-142$.

(C) 2015 by the authors; licensee MDPI, Basel, Switzerland. This article is an open access article distributed under the terms and conditions of the Creative Commons Attribution license (http://creativecommons.org/licenses/by/4.0/). 